Tropical Journal of Pharmaceutical Research September 2015; 14 (9): 1723-1731

ISSN: 1596-5996 (print); 1596-9827 (electronic)

(C) Pharmacotherapy Group, Faculty of Pharmacy, University of Benin, Benin City, 300001 Nigeria.

All rights reserved.

Available online at http://www.tjpr.org

Original Research Article

http://dx.doi.org/10.4314/tjpr.v14i9.26

\title{
Prognostic Importance of Circulating Tumor Cells in Non- small Cell Lung Cancer: A Prospective Study
}

\author{
Hong-Xia $\mathrm{Bi}^{1}$, Han-Bing Shi ${ }^{1}$, Xing-Yuan Sun ${ }^{2}$, Jiang $\mathrm{Su}^{3}$ and Zong-Fu Mao ${ }^{4 *}$ \\ ${ }^{1}$ Department of Respiratory, ${ }^{2}$ Department of Neurology, the Third Affiliated Hospital of Qiqihar Medical University, Qiqihar \\ $161000,{ }^{3}$ Department of Office, Qiqihar Medical University, Qiqihar 161006, ${ }^{4}$ Social Medicine and Health Management, School \\ of Public Health, Wuhan University, Wuhan, Hubei 430071, China
}

*For correspondence: Email: maozongfu7890@gmail.com; Tel/Fax: 0086-27-87331398

Received: 4 December 2014

Revised accepted: 20 July 2015

\begin{abstract}
Purpose: To investigate the prognostic value of circulating tumor cells (CTCs) and to predict the treatment response in a non-small cell lung cancer (NSCLC).

Methodology: A single-center prospective study involving 93 patients with NSCLC was conducted. Blood samples were analyzed for CTC count before and after chemotherapy. Clinical relevance of CTCs with patient's characteristics and treatment response were determined.

Results: Higher levels of CTCs were associated with severe stage of NSCLC ( $p=0.003)$, tumor histology $(p=0.014)$ and metastases $(p=0.013)$. Significant difference in CTC count was observed in favorable (CTCs < 5) and unfavorable (CTCs $\geq 5)$ groups. Progression-free survival (PFS) was 5.8 months (range: 5.32 to 6.43) and 2.2 months (range: 1.85 to 3.01 ) in the favorable and unfavorable groups, respectively (HR: $3.88,95 \% \mathrm{Cl}, \mathrm{p}<0.001)$. Similarly, overall survival (OS) was 7.3 months (95\% Cl, 6.51 to 7.92 ) and 3.9 months (95\% Cl, 1.99 to 5.13), respectively (HR: $4.8,95 \% \mathrm{Cl}, p<0.001$ ). Multivariate regression analysis revealed CTCs as strong predictors of OS and PFS. Significant reduction $(p<0.001)$ in CTC count was also observed after one cycle of chemotherapy.

Conclusion: Patients with low CTC count live longer and remain progression-free for a longer period of time than those with high CTC count. High CTCs can be detected in severe forms of lung cancer and can be used as a valid prognostic marker. However, this assertion requires validation in larger prospective clinical cohorts.
\end{abstract}

Keywords: Circulating tumor cells, Non-small cell lung cancer, Circulating tumor cell, Prognosis

Tropical Journal of Pharmaceutical Research is indexed by Science Citation Index (SciSearch), Scopus, International Pharmaceutical Abstract, Chemical Abstracts, Embase, Index Copernicus, EBSCO, African Index Medicus, JournalSeek, Journal Citation Reports/Science Edition, Directory of Open Access Journals (DOAJ), African Journal Online, Bioline International, Open-J-Gate and Pharmacy Abstracts

\section{INTRODUCTION}

Approximately 1.8 million people globally suffered from lung cancer in 2012 with an estimated mortality of 1.6 million [1]. Compared to USA (15.4\%), lung cancer is a predominant type of cancer in China with $21.7 \%$ of males and $14.3 \%$ of females. The incidence of lung cancer has increased by $1.63 \%$ per annum from 1988 to 2005 in China .The mortality rate of lung cancer in China was 30.84 per 100,000 in 2005 , rising by $465 \%$ over the past 30 years [2].

Primary lung cancer is generally classified into small cell lung cancer (SCLC) and non-small cell lung cancer (NSCLC), the latter accounts for 80 $85 \%$ of primary lung cancer including squamous cell carcinoma, adenocarcinoma, and large cell carcinoma. SCLC and NSCLC, named for the size of the cancer cells, when seen under a microscope. SCLC often starts in the bronchi 
near the center of the chest, and it tends to spread widely through the body fairly early in the course of the disease. On the other hand, NSCLC is comprised of bigger cells under microscope. Sometimes SCLC and NSCLC both can exist in one patient termed as Combined SC/NSC lung carcinoma [3]. The overall survival rate of NSCLC is given in Table 1.

Table 1: Five years survival rate of NSCLC according to Lung Cancer Staging project [4]

\begin{tabular}{lc}
\hline Stage & 5-year survival rate \\
\hline IA & $58-73 \%$ \\
IB & $43-58 \%$ \\
IIA & $36-46 \%$ \\
IIB & $25-36 \%$ \\
IIIA & $19-24 \%$ \\
IIIB & $7-9 \%$ \\
IV & $2-13 \%$ \\
\hline
\end{tabular}

The high mortality seen in NSCLC is due to the presence of distant metastasis. Currently tumor histology and stage are used as prognostic factors in NSCLC. Sometimes, in patients without clinically detectable distant metastasis, distant micro metastases frequently develop during diagnosis, even undergoing surgery [5] Moreover, the lack of pharmacodynamics biomarkers has hindered successful drug development in lung cancer research. These biomarkers report early indication of response or otherwise treatment [6]. Therefore, sensitive prognostic and predictive markers is urgently needed in lung oncology.

Circulating tumor cells (CTCs) are tumor cells that shed from primary tumors and circulate through blood streams and result in formation of metastases. CTCs are rare cells among the billions of normal cells. Thirteen methods have been described to identify these cells and amongst them, Cell Search method which enumerates CTCs is the only FDA approved method [7].

Prognostic significance of CTCs and changes in CTCs number with standard therapy in different tumors have been elucidated [8-10]. CTCs have also been demonstrated as predictive biomarker in patients with small cell lung cancer (SCLC) [11]. Only a few reports have been published on CTCs in NSCLC [6, 12-15]. There is still paucity of data demonstrating prognostic significance of CTCs in NSCLC.

Therefore current study was conducted to determine clinical importance of CTCs in NSCLC.

\section{METHODS}

Single center prospective study was conducted in the outpatient oncology clinic of third affiliated Hospital of Qiqihar Medical University Hospital. Inclusion criteria for the current study was histologically and cytologically confirmed NSCLC patients, patients with either lung cancer stage IIIA, IIIB or IV, chemotherapy naïve, patients having evaluable and measureable disease, WHO performance status (PS): $0-2$, no active concurrent malignancy and patients willing to participate in study.

The following category of patients were excluded from the study: those having prior palliative radiotherapy for primary tumor and metastases $>$ 5 weeks, history of prior malignancy within 5 years of study entry, inadequate bone marrow, hepatic and renal functions.. Stage of cancer was determined by using chest $X$ ray, computed tomography (CT) of the chest and abdomen, brain magnetic resonance imaging (MRI) and positron emission tomography (PET). The study methodology is schematically described in Figure 1.

For CTC analysis, peripheral blood sampling was done within seven days before initiation of treatment (platinum doublet and single agent chemotherapy according to patient need) and after one cycle of chemotherapy. CTC count before treatment served as the baseline value. Standard operating procedures and good clinical practices were applied during CTC analysis.

CellSearch method was used for CTC analysis. Blood samples were taken and stored in CellSave conservative bottle $(10 \mathrm{ml})$ at room temperature. All the stored samples were processed within 96 hours according to manufacturer's instruction $[6,11]$. CTC counting was carried out without knowledge of patient's clinical characteristics. CTCs count were blinded to physicians treating the patients and independently merged with clinical data. According to findings by Allard et al [16], CTC count of 1 has been considered as a normal in healthy donors or patients with benign disease. Therefore a CTC count $\geq 2$ in $7.5 \mathrm{ml}$ of blood was considered in current study. Ethical approval was obtained from the hospital ethical review board (Ref. No. QMUHRB/216/2011) of Qiqihar Medical University hospital. For the human protection in current study guidelines of Declaration of Helsinki (7th revision) were applied to enrolled subjects. 


\section{Statistical analysis}

According to previous studies evaluating prognostic significance of CTCs in different types of cancers, patients were categorized into "favorable" and "unfavorable" groups based upon baseline CTC count. Assuming survival as end point of our study, we determined the most suitable cutoff value of CTCs for division of participants into favorable and unfavorable groups. Kaplan-Meier method was used to estimate the survival function of a series of baseline CTC values ranging from 1 to 10 . After applying bonferroni correction factor, CTCs count 5 was the only statistically significant factor that

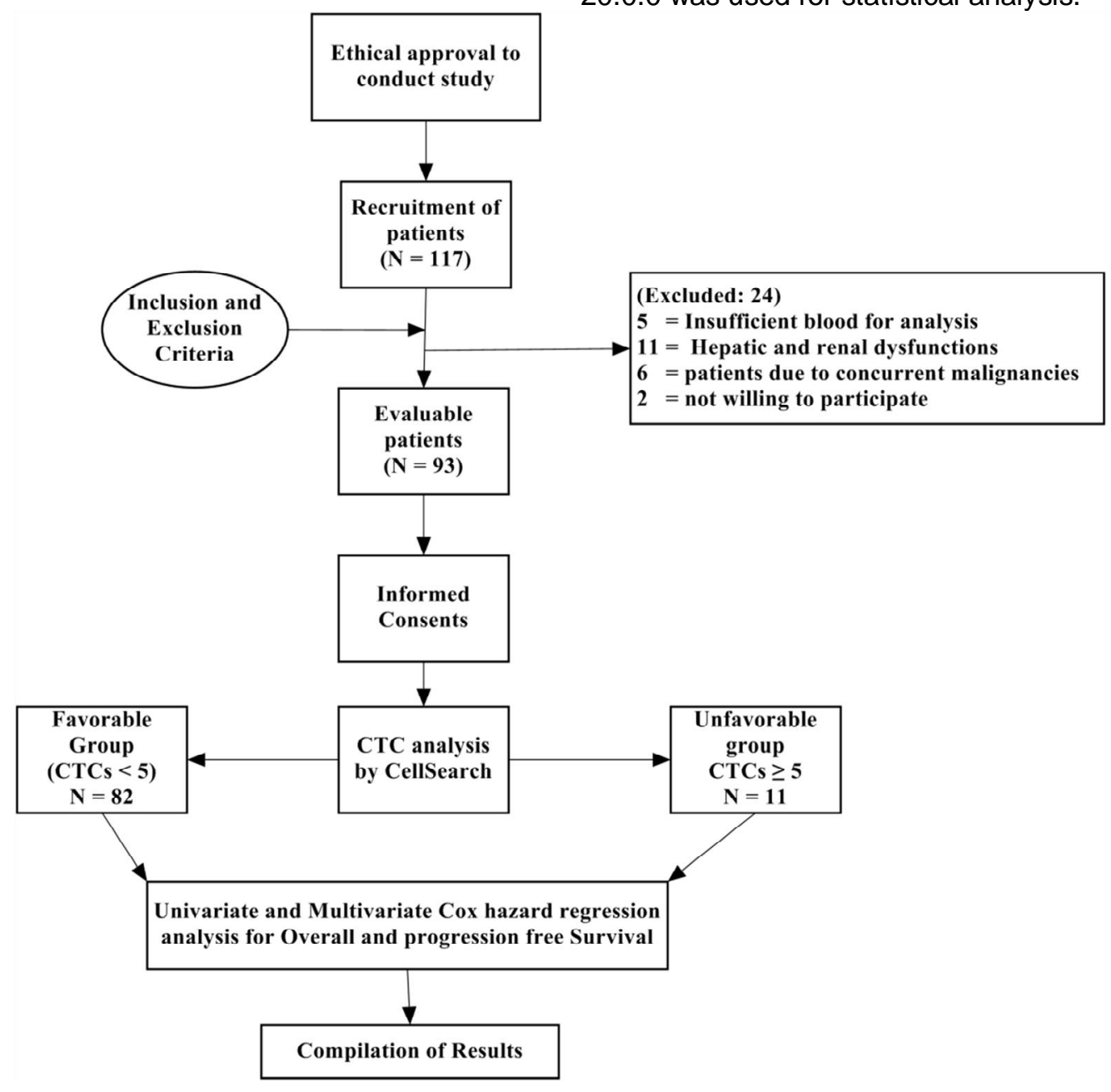

Figure 1: Flow sheet of study methodology

Table 2: Bonferroni method of correction to determine most significant CTC cutoff for survival

\begin{tabular}{lccc}
\hline $\begin{array}{l}\text { Cutoff } \\
\text { (CTC count) }\end{array}$ & $\boldsymbol{P}$-value & $\boldsymbol{p} \times \mathbf{1 0}$ & $\begin{array}{c}\text { Significant after } \\
\text { correction (Yes/No) }\end{array}$ \\
\hline 1 & 0.007 & 0.07 & No \\
2 & 0.006 & 0.06 & No \\
3 & 0.298 & 2.98 & No \\
4 & 0.088 & 0.88 & No \\
5 & $<0.0001$ & $<0.001$ & Yes \\
\hline
\end{tabular}

showed discriminative survival estimation (Table 2).

Univariate Cox proportional hazards regression analysis were done to determine significant prognostic factors related to progression free survival (PFS) and overall survival (OS). As a result of Univariate analysis only statistical significant parameters were included in multivariate cox proportional hazards analysis. PFS and OS were calculated from the date of baseline blood sample to date of death or were censored at last follow-up (confirmed clinical progression in case of PFS only). Considering $p$ $\leq 0.05$ as statistically significant SPSS version 20.0.0 was used for statistical analysis. 


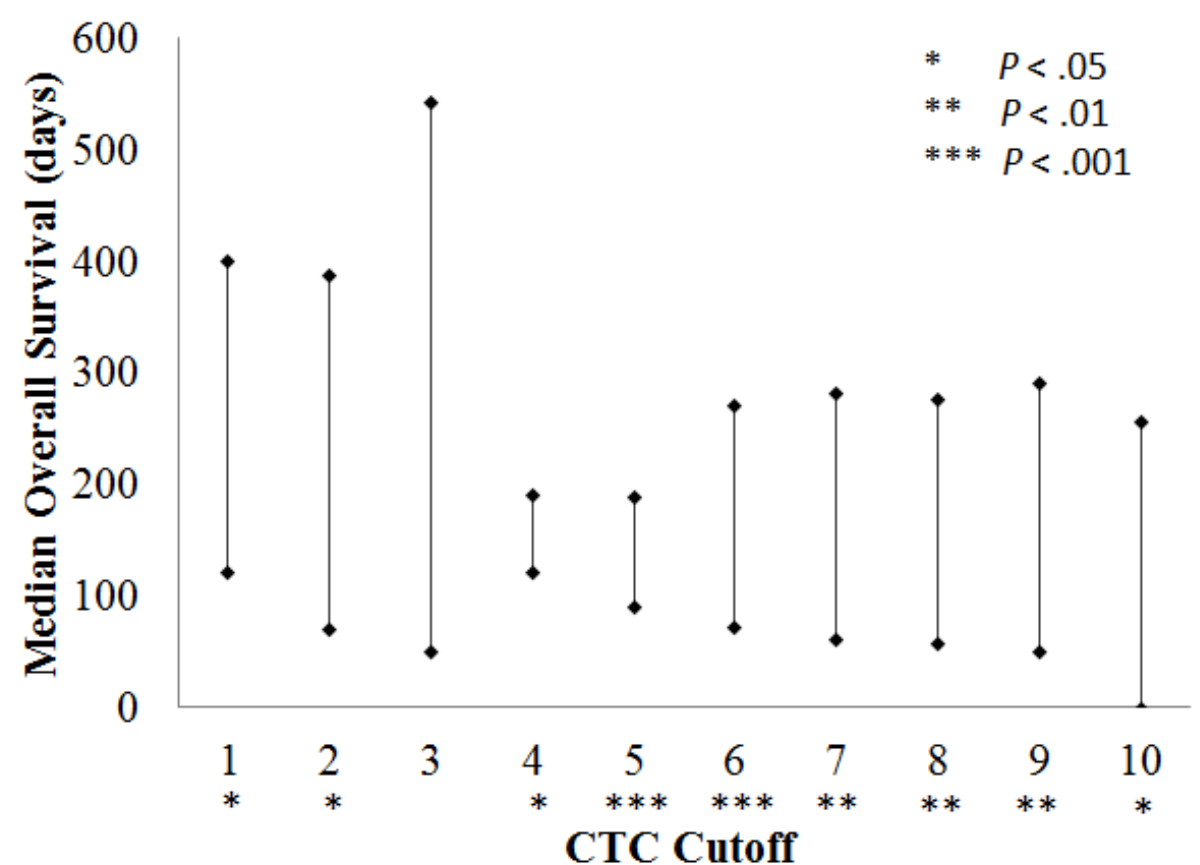

Figure 2: Range of CTC cutoff values for Overall Survival (OS) (Kaplan-Meier Analysis)

\section{RESULTS}

One hundred and seventeen (117) patients diagnosed with NSCLC were consecutively included in current study. Patient's demographics and characteristics are given in Table 3. Twenty four (24) patients were excluded from study after application of the exclusion criteria (five patients due to insufficient blood for analysis, eleven patients due to hepatic and renal dysfunctions, six patients due to concurrent malignancies and two patients were not willing to participate in study). Written consents were taken from all evaluable 93 patients.

All the patients were subjected to CTCs enumeration before initiation of therapy. They were divided into five classes according to CTCs count (CTC $\leq 1,2,3,4, \geq 5)$. Association of CTCs count with patient's characteristics and sites of metastasis can be seen in table 4 and table 5. High CTCs count is strongly associated with stage and histology of tumors (Fisher's exact test $p$-value: 0.003 and .014 respectively). Significant association of CTC was also observed with bone and liver metastasis (Fisher's exact test $p$-value: 0.021 and 0.013 respectively). The number of metastasis sites were also significantly associated with high CTCs count (Fisher's exact test p-value: 0.001). Performance score and smoking status were not associated with CTC (Fisher's exact test $p$-value: 0.295 and 0.211 respectively).
Table 3: Participants demographics and clinical characteristics

\begin{tabular}{cc}
\hline Characteristic & Number (\%) \\
\hline $\begin{array}{c}\text { Age (Mean } \pm \text { SD) } \\
\text { Gender }\end{array}$ & $68 \pm 11$ \\
Male & $55(58 \%)$ \\
Female & $38(42 \%)$ \\
Smoking status & \\
Non-Smoker & $28(30 \%)$ \\
Former Smoker & $12(13 \%)$ \\
Current Smoker & $53(57 \%)$ \\
IIIA & \\
IIIB & $5(5 \%)$ \\
IV & $11(12 \%)$ \\
Adenocarcinoma & $77(83 \%)$ \\
Squamous cell carcinoma & $26(28 \%)$ \\
Undifferentiated & $18(19 \%)$ \\
Others & $9(10 \%)$ \\
Tumor histology & $40(43 \%)$ \\
0 & $20(22 \%)$ \\
1 & $66(71 \%)$ \\
2 & $7(8 \%)$ \\
Baseline WHO performance status & $11(12 \%)$ \\
Single Therapy & $77(83 \%)$ \\
Double Therapy & $5(5 \%)$ \\
No treatment given &
\end{tabular}

All the evaluable patients were divided into favorable (CTCs < 5) and unfavorable (CTCs $\geq$ 5 ) groups according to the baseline CTC count. Out of the 93 patients, 82 (88\%) patients belonged to the favorable group while 11 (12\%) patients were included in the unfavorable group. During the study period, (45) $55 \%$ of 82 patients from the favorable group and $8(72 \%)$ of 11 from the unfavorable group had tumor progression. 
Table 4: Association of CTCs with clinical characteristics

\begin{tabular}{|c|c|c|c|c|c|c|c|c|c|c|c|c|c|c|c|c|c|c|c|c|c|c|}
\hline & \multicolumn{3}{|c|}{ Tumor Stage } & \multirow[t]{2}{*}{$P^{* *}$} & \multicolumn{3}{|c|}{ WHO PS } & \multirow[t]{2}{*}{$P^{* \star}$} & \multicolumn{3}{|c|}{ Smoking Status } & \multirow[t]{2}{*}{$P^{* *}$} & \multicolumn{4}{|c|}{ Tumor Histology } & \multirow[t]{2}{*}{$P^{* *}$} & \multicolumn{4}{|c|}{$\begin{array}{c}\text { No. of metastasis } \\
\text { sites }\end{array}$} & \multirow[t]{2}{*}{$P^{\star \star}$} \\
\hline & $\begin{array}{l}\text { IIIA } \\
5^{*}\end{array}$ & $\begin{array}{c}\text { IIIB } \\
11\end{array}$ & $\begin{array}{l}\text { IV } \\
77\end{array}$ & & $\begin{array}{c}0 \\
20\end{array}$ & $\begin{array}{c}1 \\
66\end{array}$ & $\begin{array}{l}2 \\
7\end{array}$ & & $\begin{array}{l}\mathbf{N} \\
28\end{array}$ & $\begin{array}{l}\mathbf{C} \\
53\end{array}$ & $\begin{array}{c}\mathbf{F} \\
12\end{array}$ & & $\begin{array}{l}A C \\
26\end{array}$ & $\begin{array}{c}\text { SCC } \\
18\end{array}$ & $\begin{array}{c}\text { UD } \\
9\end{array}$ & $\begin{array}{c}0 \\
40\end{array}$ & & $\begin{array}{c}0 \\
44\end{array}$ & $\begin{array}{c}1 \\
33\end{array}$ & $\begin{array}{c}2 \\
10\end{array}$ & $\begin{array}{c}3+ \\
6\end{array}$ & \\
\hline $\begin{array}{l}\text { CTC } \\
<1\end{array}$ & 4 & 8 & 26 & .002 & 0 & 28 & 1 & .003 & 0 & 29 & 6 & .021 & 0 & 16 & 0 & 20 & .045 & 42 & 3 & 0 & 0 & .001 \\
\hline $\begin{array}{l}\text { CTCs } \\
\geq 2\end{array}$ & 1 & 2 & 17 & .003 & 4 & 15 & 3 & .295 & 16 & 8 & 3 & .211 & 10 & 1 & 4 & 7 & .014 & 2 & 10 & 3 & 2 & .001 \\
\hline $\begin{array}{l}\text { CTCs } \\
\geq 3\end{array}$ & 0 & 1 & 13 & .012 & 4 & 10 & 1 & .291 & 10 & 7 & 1 & .161 & 6 & 1 & 2 & 6 & .013 & 0 & 8 & 3 & 2 & .001 \\
\hline $\begin{array}{l}\text { CTCs } \\
\geq 4\end{array}$ & 0 & 0 & 10 & .021 & 7 & 7 & 1 & .401 & 2 & 5 & 1 & .257 & 6 & 0 & 2 & 4 & .017 & 0 & 6 & 2 & 1 & .003 \\
\hline $\begin{array}{l}\text { CTCs } \\
\geq 5\end{array}$ & 0 & 0 & 11 & .05 & 5 & 6 & 1 & .211 & 0 & 4 & 1 & .333 & 4 & 0 & 1 & 3 & .041 & 0 & 6 & 2 & 1 & .002 \\
\hline
\end{tabular}

${ }^{\star}$ All the numbers given in tables are total number of patients, ${ }^{* *}$ Fisher's exact test; $P S$ : performance score, N: non-smoker, C: current smoker, F: former smoker, O: others, AC: adenocarcinoma, SCC: squamous cell carcinoma, UD: undifferentiated, CTC: circulating tumor cell

Table 5: Site of metastasis in studied population

\begin{tabular}{|c|c|c|c|c|c|c|c|c|c|c|c|c|c|c|c|c|c|c|}
\hline & \multicolumn{2}{|c|}{$\begin{array}{l}\text { Adrenal } \\
\text { System }\end{array}$} & \multirow[t]{2}{*}{$P^{* *}$} & \multicolumn{2}{|c|}{ Brain } & \multirow[t]{2}{*}{$P^{\star \star}$} & \multicolumn{2}{|c|}{ Bone } & \multirow[t]{2}{*}{$P^{\star \star}$} & \multicolumn{2}{|c|}{ Lymph Node } & \multirow[t]{2}{*}{$P^{\star \star}$} & \multicolumn{2}{|c|}{ Liver } & \multirow[t]{2}{*}{$P^{\star \star *}$} & \multicolumn{2}{|c|}{ Pulmonary System } & \multirow[t]{2}{*}{$P^{\star \star}$} \\
\hline & $\begin{array}{l}\text { Yes } \\
14^{*}\end{array}$ & $\begin{array}{l}\text { No } \\
79\end{array}$ & & $\begin{array}{c}\text { Yes } \\
3\end{array}$ & $\begin{array}{c}\text { No } \\
90\end{array}$ & & $\begin{array}{c}\text { Yes } \\
13\end{array}$ & $\begin{array}{c}\text { No } \\
80\end{array}$ & & $\begin{array}{c}\text { Yes } \\
11\end{array}$ & $\begin{array}{l}\text { No } \\
82\end{array}$ & & $\begin{array}{c}\text { Yes } \\
9\end{array}$ & $\begin{array}{l}\text { No } \\
84\end{array}$ & & $\begin{array}{l}\text { Yes } \\
29\end{array}$ & $\begin{array}{l}\text { No } \\
64\end{array}$ & \\
\hline CTC $<1$ & 7 & 32 & .031 & 1 & 42 & .002 & 1 & 52 & .016 & 2 & 38 & .021 & 0 & 36 & .011 & 11 & 31 & .011 \\
\hline CTCs $\geq 2$ & 2 & 19 & .782 & 0 & 15 & .031 & 4 & 14 & .021 & 4 & 16 & .417 & 4 & 15 & .013 & 7 & 12 & .887 \\
\hline CTCs $\geq 3$ & 2 & 12 & .811 & 0 & 14 & .033 & 3 & 7 & .033 & 3 & 12 & .871 & 2 & 11 & .012 & 6 & 9 & .431 \\
\hline CTCs $\geq 4$ & 2 & 9 & .871 & 1 & 10 & . 167 & 3 & 4 & .047 & 1 & 9 & 891 & 2 & 6 & .031 & 3 & 7 & .977 \\
\hline $\mathrm{CTCs} \geq 5$ & 1 & 7 & .813 & 1 & 9 & .235 & 2 & 3 & .048 & 1 & 7 & .987 & 1 & 5 & .002 & 2 & 5 & .989 \\
\hline
\end{tabular}

${ }^{*}$ All the numbers given in tables are total number of patients, ${ }^{* *}$ Fisher's exact test 
The risk factors of tumor progression were determined by univariate and multivariate survival analysis. Univariate analysis showed tumor stage (HR: 2.37), WHO PS (HR: 8.87) and treatment (HR: 0.09), which are significant factors for progression free survival (PFS) as shown in Table 6.

All the evaluable patients were divided into favorable (CTCs < 5) and unfavorable (CTCs $\geq$ 5) groups according to the baseline CTC count. Out of the 93 patients, 82 (88\%) patients belonged to the favorable group while 11 (12\%) patients were included in the unfavorable group. During the study period, (45) $55 \%$ of 82 patients from the favorable group and $8(72 \%)$ of 11 from the unfavorable group had tumor progression. The risk factors of tumor progression were determined by univariate and multivariate survival analysis. Univariate analysis showed tumor stage (HR: 2.37), WHO PS (HR: 8.87) and treatment (HR: 0.09), which are significant factors for progression free survival (PFS) as shown in Table 6.

All the significant predictors were subjected to multivariate cox proportion hazards regression analysis. CTCs $\geq 5$ at baseline (HR: 4.23), CTCs $\geq 5$ at two time points (pretreatment and after one cycle of chemotherapy) (HR: 9.84), worse WHO PS (HR: 10.72) and severe tumor stage (HR: 1.96) were significant predictors for poor progression free survival as shown in Table 7.
The median time to progression was 5.8 months (95\% Cl, 5.32 to 6.43 ) in the favorable group and 2.2 months $(95 \% \mathrm{Cl}, 1.85$ to 3.01$)$ in the unfavorable groups. According to Univariate cox proportional analysis, hazards regression $\mathrm{HR}$ was $3.88(p<.001)$ with $95 \% \mathrm{Cl}$.

At the time of analysis, 44 (54\%) of 82 patients in the favorable group and $3(27 \%)$ of 11 patients in the unfavorable were alive. Significant predictors associated with overall survival (OS) are given in Table 8. The median OS was 7.3 months (95\% Cl, 6.51 to 7.92) for favorable group and 3.9 months (95\% Cl, 1.99 to 5.13) for unfavorable group. According to Univariate cox proportional analysis, hazards regression $\mathrm{HR}$ was $4.86(p<.001)$ with $95 \% \mathrm{Cl}$. Adrenal, bone and renal metastases were also significantly associated with overall survival in studied patients.

CTC analysis after one cycle of standard chemotherapy was performed in patients having CTC counts $\geq 2$. A dynamic change in CTC count was observed in all patients $(n=24)$ as shown in figure 3. Reduction in CTC count after one cycle of chemotherapy was observed in 19 (79\%) patients. Elevation in CTC counts were observed in $4(17 \%)$ patients while in one $(4 \%)$ patient CTC levels were constant after treatment. Patients in which reduction of CTC count was observed had significant $(p<0.01)$ progression free survival and overall survival as compared to those in which CTC count was increased.

Table 6: Univariate analysis to determine risk factors for progression free survival (PFS)

\begin{tabular}{|c|c|c|c|c|}
\hline $\begin{array}{l}\text { Clinical } \\
\text { Characteristics }\end{array}$ & Unfavorable group & Favorable Group & $P$-value & $\begin{array}{c}\text { Hazard ratio } \\
\text { (HR) }\end{array}$ \\
\hline $\begin{array}{l}\text { Baseline } \\
\text { count }\end{array}$ & $\geq 5$ & $<5$ & $<.001$ & 3.96 \\
\hline Tumor stage & IV & IIIA \& IIIB & 0.018 & 2.37 \\
\hline WHO PS & \multicolumn{2}{|c|}{$2 v 1 v 0$} & $<.001$ & 8.87 \\
\hline Treatment & Dual platinum therapy & Single therapy & $<.001$ & 0.09 \\
\hline Liver metastasis & Present & Absent & .038 & 2.04 \\
\hline
\end{tabular}

Table 7: Multivariate analysis to determine risk factors for progression-free survival (PFS)

\begin{tabular}{lcccc}
\hline $\begin{array}{l}\text { Clinical } \\
\text { characteristic }\end{array}$ & Favorable group & Unfavorable Group & P-value & $\begin{array}{c}\text { Progression free } \\
\text { survival risk (HR) }\end{array}$ \\
\hline $\begin{array}{l}\text { Baseline CTCs count } \\
\text { CTC at two time points }\end{array}$ & $\begin{array}{c}\geq 5 \text { at either time } \\
\text { point }\end{array}$ & $\begin{array}{c}<5 \text { at both before and } \\
\text { after treatment }\end{array}$ & $<.001$ & 4.23 \\
Tumor stage & IV & IIIA \& IIIB & .001 & 9.84 \\
WHO PS & & $2 v 1 v 0$ & $<2$ & 1.96 \\
\hline
\end{tabular}

PFS: progression free survival, CTCs: circulating tumor cells, WHO PS: World Health Organization performance status, HR: hazard ratio 
Table 8: Univariate and multivariate analysis to determine risk factors for overall survival (OS)

\begin{tabular}{|c|c|c|c|c|}
\hline $\begin{array}{l}\text { Clinical } \\
\text { Characteristics }\end{array}$ & Unfavorable group & Favorable Group & $P$-value & Hazard ratio (HR) \\
\hline \multicolumn{5}{|c|}{ Univariate analysis } \\
\hline Baseline CTCs & $\geq 5$ & $<5$ & $<.001$ & 5.24 \\
\hline count & & & & \\
\hline Tumor stage & IV & IIIA \& IIIB & .044 & 1.98 \\
\hline WHO PS & \multicolumn{2}{|c|}{$2 v 1 v 0$} & .008 & 4.21 \\
\hline Treatment & Dual Platinum therapy & Single therapy & .031 & 0.15 \\
\hline Liver metastasis & Present & Absent & .020 & 2.35 \\
\hline Bone metastasis & Present & Absent & .041 & 1.97 \\
\hline Adrenal metastasis & Present & Absent & .033 & 2.13 \\
\hline $\begin{array}{l}\text { Clinical } \\
\text { Characteristics }\end{array}$ & Unfavorable group & Favorable Group & $P$-value & Hazard ratio (HR) \\
\hline \multicolumn{5}{|c|}{ Multivariate Analysis } \\
\hline $\begin{array}{l}\text { Baseline } \\
\text { count }\end{array}$ & $\geq 5$ & & $<.001$ & 6.38 \\
\hline $\begin{array}{l}\text { CTC at two time } \\
\text { points }\end{array}$ & $\geq 5$ at either time point & & $<.001$ & 13.64 \\
\hline $\begin{array}{l}\text { Adrenal metastasis } \\
\text { WHO PS }\end{array}$ & \multicolumn{2}{|c|}{$2 v 1 v 0$} & $\begin{array}{l}.031 \\
.008\end{array}$ & $\begin{array}{c}2.13 \\
11.89\end{array}$ \\
\hline
\end{tabular}

PFS: progression free survival, CTCs: circulating tumor cells, WHO PS: World Health Organization performance status, HR: hazard ratio

Out of 23 patients with no CTCs at baseline, one patient had CTCs after chemotherapy. This patient had stage IV disease and died at 3.1 months. Progression free survival and overall survival was better in patients having no CTCs at baseline as compared to those having CTCs at baseline $(p<0.001)$. Progression free survival after one cycle of treatment in favorable and unfavorable groups was 7.1 months and 2.7 months respectively. On the other hand, overall survival after one cycle of treatment in favorable and unfavorable groups was 7.9 months and 4.1 months respectively.

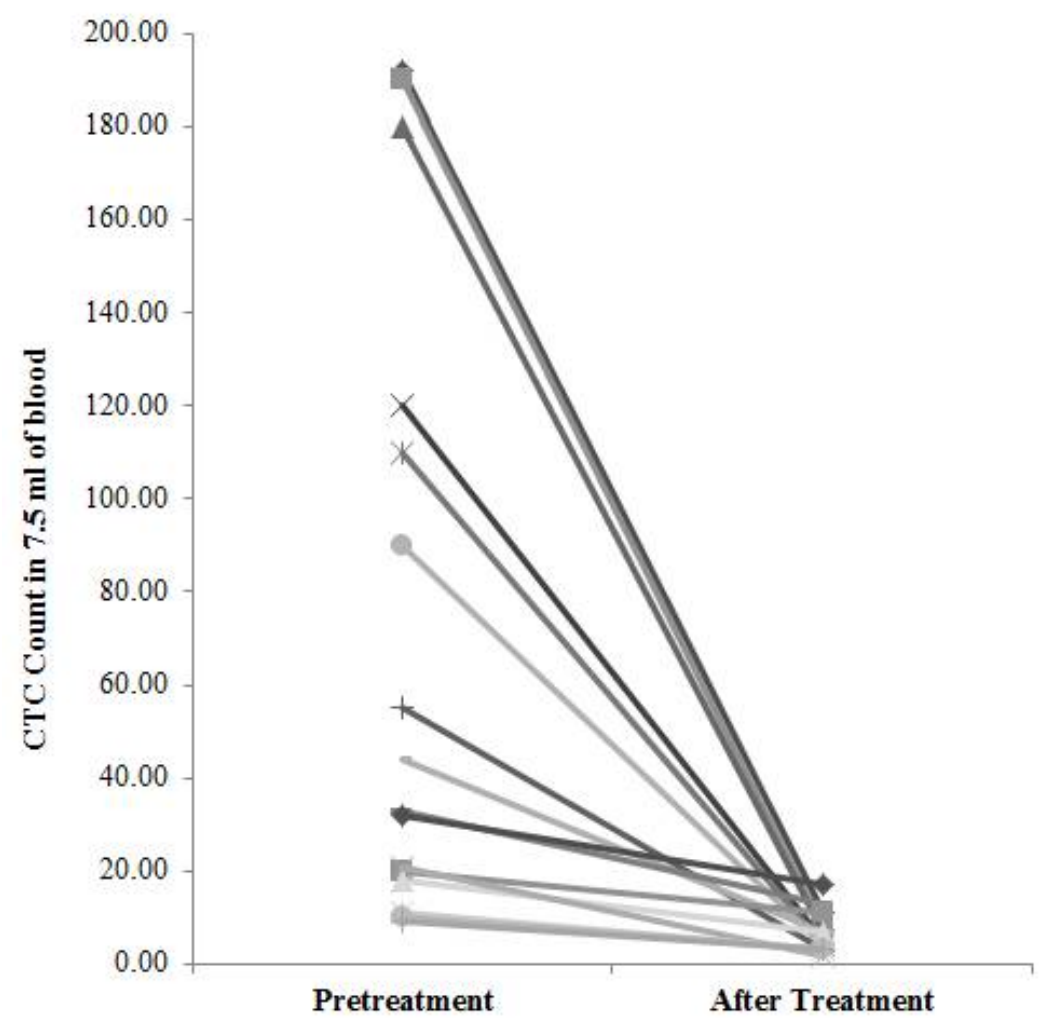

Figure 3: Change in CTCs count before and after one cycle of chemotherapy in CTC positive (CTCs count $\geq 2$ ) patients $(n=24)$ [Each line represents one patients, these are 24 lines representing 24 patients] 
Significant reduction $(p<0.01)$ in CTCs count was observed in patients having high (> 80) values of CTCs as compared those having low $(<$ 30) CTC count.

\section{DISCUSSION}

Primary lung cancer is one of the leading causes of cancer-related deaths in industrialized regions. Distant metastases can be present in approximately $40 \%$ of patients that may result in fatal cases. These metastases may develop during or after chemotherapy and can be detected by current diagnostic modalities. Circulating tumor cells in peripheral blood may cause development of clinically apparent distant metastases. Therefore detection of such circulating cells (CTCs) may improve diagnosis and therapy in patients suffering from primary lung cancer [17].

The potential advantage of a CTC test may be its ability to predict the presence of a micrometastasis that is undetectable with routine diagnostic modalities. Prognostic significance in different tumors has been well established [8-10]. Moreover few reports have demonstrated the clinical significance of CTCs with small cell lung cancer (SCLC) [11] and its prognostics significance has also been studied in NSCL [6]. But there is still scarcity of data showing importance of CTCs enumeration during the treatment of NSCLC.

We performed a prospective single center study to evaluate the prognostic importance of CTCs in NSCLC. All the studied participants with metastatic disease had $\geq 2$ CTCs. A significant ( $p$ $<.001)$ difference in progression free survival (PFS) and overall survival (OS) were observed between the favorable and unfavorable groups. Similarly patients with $\geq 5$ CTCs had worse prognosis after chemotherapy as compared to favorable group's participants. We found that an increasing number of CTCs is directly proportional to a worse clinical picture of nonsmall cell lung cancer i.e. high WHO-PS and severe tumor stage. CTCs count were $\mathrm{s}$ significantly reduced after one cycle of chemotherapy and this reduction was more significant in patients with CTCs count $>80$. We found several patients without CTC (negative CTC) even in severe stages of NSCLC. It might be due to formation of very small microemboli by CTCs that were not detected by the CellSearch system.

For CTCs enumeration, we used the CellSearch system that has been extensively validated in patients with metastatic carcinomas. We used 5
CTCs as a cutoff value because this value has previously been reported as prognostic in different tumors in several large multicenter trials $[8,11]$.

The findings of our studies are consistent with Krebs et al [6]. The median progression free survival in Kreb's study among two studied cohorts (< 5 CTCs vs $\geq 5$ CTCs) was 6.8 months and 2.4 months respectively. Similarly overall survival was 8.1 months and 4.3 months respectively. Though number of patients is insignificantly less in our study (101 vs 93) but the number of patients for who a post-treatment blood sample was obtained was high in our study (18 vs 24). Our findings are comparable with Krebs study data.

\section{Limitations of the study}

The major limitations of the current study were that the study population was small and the study was performed at a single institution. In addition, the study population included patients treated by chemoradiotherapy as well as patients who were treated by chemotherapy alone. Since the purposes of chemotherapy and chemoradiotherapy are different, separate derivation studies are required to determine the optimal threshold value of the CTC count.

\section{CONCLUSION}

The findings of this study support the fact that CTCs are associated with tumor stage, metastasis and WHO PS. The presence of CTCs results in poor prognosis and higher levels of CTCs are related to both poor progression-free survival and overall survival. CTC enumeration may help in the selection of therapy, evaluation of patients to ascertain whether they are benefiting from treatment or not, and the decision to administer adjuvant therapy. Larger prospective clinical cohorts are required for the validation of the results of this study.

\section{ACKNOWLEDGEMENT}

The authors are grateful for the support received from the outpatient oncology clinic of Qiqihar Medical University Hospital and the provision of technical support during the study.

\section{REFERENCES}

1. Brambilla E, Travis WD. Lung cancer. In: World Cancer Report, Stewart BW, Wild CP (Eds), World Health Organization, Lyon 2014 
2. Wang YC, Wei LJ, LiU JT, Li SX, Wang QS. Comparison of Cancer Incidence between China and the USA. Cancer Biol Med 2012; 9(2): 128- 132.

3. Tanaka FYK, Hasegawa S. Circulating tumor cells (CTCs) in lung cancer: current status and future perspectives. Lung Cancer: Targets and Therapy 2010; $1: 77$ - 84.

4. Goldstraw P, Crowley J, Chansky K, Giroux DJ, Groome $P A$, Rami-Porta $R$ and International Association for the Study of Lung Cancer International Staging Committee. (2007). The IASLC Lung Cancer Staging Project: Proposals for the revision of the TNM stage groupings in the forthcoming (7th) edition of the TNM Classification of malignant tumours. $J$ Thorac Oncol 2007; 2(8): 706-714.

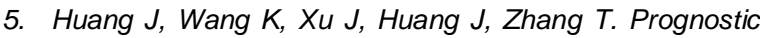
Significance of Circulating Tumor Cells in Non-SmallCell Lung Cancer Patients: A Meta-Analysis. PloS One 2013; 8(11): e78070.

6. Krebs MG, Sloane R, Priest L, Lancashire L, Hou JM, Greystoke A, Ward TH, Ferraldeschi R, Hughes A, Glen $C$ et al. Evaluation and prognostic significance of circulating tumor cells in patients with non-smallcell lung cancer. J Clin Oncol 2011; 29(12): 1556 1563.

7. Boshuizen R, Kuhn P, Van Den Heuvel M. Circulating tumor cells in non-small cell lung carcinoma. Journal of thoracic disease 2012; 4(5): 456.

8. Cristofanilli M, Budd GT, Ellis MJ, Stopeck A, Matera J, Miller MC. Circulating tumor cells, disease progression, and survival in metastatic breast cancer. New Eng J Med 2004; 351(8): 781-791.

9. Cohen SJ, Punt CJ, lannotti N, Saidman BH, Sabbath KD, Gabrail NY, Picus J, Morse M, Mitchell E, Miller $M C$ et al. Relationship of circulating tumor cells to tumor response, progression-free survival, and overall survival in patients with metastatic colorectal cancer. J Clin Oncol 2008; 26(19): 3213 - 3221.

10. De Bono JS, Scher HI, Montgomery RB, Parker C, Miller MC, Tissing H, Doyle GV, Terstappen LWWM, Pienta $K J$, Raghavan $D$ Circulating tumor cells predict survival benefit from treatment in metastatic castration-resistant prostate cancer. Clin Cancer Res 2008; 14(19): 6302 - 6309.

11. Hou JM, Greystoke A, Lancashire L, Cummings J, Ward $T$, Board R, Amer E, Hughes S, Krebs M, Hughes A et al. Evaluation of circulating tumor cells and serological cell death biomarkers in small cell lung cancer patients undergoing chemotherapy. $A m \mathrm{~J}$ Pathol 2009; 175(2): 808 - 816.

12. Wendel M, Bazhenova L, Boshuizen $R$, Kolatkar $A$, Honnatti $M$, Cho $E H$, Marrinuchii $D$, Sandhu $A$, Perricone A, Thistlethwaite $P$ et al. Fluid biopsy for circulating tumor cell identification in patients with early-and late-stage non-small cell lung cancer: a glimpse into lung cancer biology. Physical Biol 2012; 9(1): 016005.

13. Das M, Riess JW, Frankel $P$, Schwartz E, Bennis $R$, Hsieh $H B$ et al. ERCC1 expression in circulating tumor cells (CTCS) using a novel detection platform correlates with progression-free survival (PFS) in patients with metastatic non-small-cell lung cancer (NSCLC) receiving platinum chemotherapy. Lung Cancer 2012; 77(2): 421 - 426.

14. Devriese LA, Bosma AJ, Van De Heuvel MM, Heemsbergen $W$, Voest EE, Schellens JHM. Circulating tumor cell detection in advanced nonsmall cell lung cancer patients by multi-marker QPCR analysis. Lung Cancer 2012; 75(2): 242 - 247.

15. Hofman V, Bonnetaud C, llie MI, Vielh P, Vignaud, JM, Fléjou JF, Hofman P. Preoperative circulating tumor cell detection using the isolation by size of epithelial tumor cell method for patients with lung cancer is a new prognostic biomarker. Clin Cancer Res 2011; 17(4): 827 - 835.

16. Allard WJ, Matera J, Miller MC, Repollet M, Connelly MC, Rao C, Terstappen LW. Tumor cells circulate in the peripheral blood of all major carcinomas but not in healthy subjects or patients with nonmalignant diseases. Clin Cancer Res 2004; 10(20): 6897 6904.

17. Tanaka FYK, Yoneda K, Hasegawa S. Circulating tumor cells (CTCS) in lung cancer: current status and future perspectives. Lung Cancer: Targets and Therapy 2010; $1: 77$ - 84. 